and south-east they are brought against similar strata by a powerful north-easterly fault.

In Scotland the Moine Schists have long been known to occupy vast areas, both in the Northern Highlands, and in the Central Highlands where they pass southwards under the Dalradian. Their reappearance on the south-west side of the latter in Ireland not only greatly extends the known range of the Moine Schists, but also suggests that they form a basement for much, if not all, of the younger Dalradian formation.

On completion of further field and petrographic work it is hoped to publish a more detailed account.
19 Grange Terrace,
Edinburgh.
17 th July, 1946.
J. G. C. Anderson.

\title{
CAEN UNIVERSITY GEOLOGY DEPARTMENT
}

SIR,--In Volume 81, No. 5 (Sept.-Oct., 1944) you were good enough to publish our appeal on behalf of the Geology Department of Caen University. We would like to thank the numerous donors who responded beyond our hopes, and we think it would interest them individually to know what they have collectively enabled us to do to help Caen in its plight.

Donations amounted to $£ 1467 s$., of which we have spent $£ 645 s$. $6 \mathrm{~d}$. on British geological books and maps, and some $£ 20$ on a prism binocular, pocket lenses, and Canada balsam, all asked for by Professor Dangeard. The most valuable single donation in kind was a set of the Quarterly Journal from vol. 23 (1867) to the present day, presented by Mr. A. G. Stenhouse, together with numerous Survey memoirs and Summaries of Progress, and a dozen standard geological books now for the most part unobtainable. Bristol University are sending independently 13 more volumes of the Quarterly Journal, taking the set back to volume 10 (1854), a nearly complete set of the Palaeontographical Society's monographs and a nearly complete run of the Geological Magazine from Vol. 1 to, Vol. 67 (1930). We have completed the Geological Magazine as far as it is in print, at a cost of $£ 2318 \mathrm{~s}$. $6 d$., and the Council of the Palaeontographical Society has presented the parts needed to complete the set of their monographs. We have also been promised a run of the Proceedings of the Geologists' Association from 1920 to 1944. In addition, we have received and forwarded about $40 \mathrm{lb}$. of reprints and, through the War Office, a set of 85 maps of France on the 1/80,000 scale; and other donors have sent representative collections of labelled British Cretaceous and Tertiary fossils. It is proposed to hold the remainder of our funds in reserve for the purchase of other books asked for by Professor Dangeard, but not at present obtainable, and important Geological Survey publications as they become available.

We are indebted to the British Council for forwarding the books and collections piecemeal. Everything sent has been reported by Professor Dangeard as arrived in good condition.

10 th May, 1946.

J. A. Douglas,
W. B. R. KING,
C. J. STUBbLEFIELd,
C. W. Wright,
W. J. ARKELL.


Geo. Mag. 1946.

Plate XV.

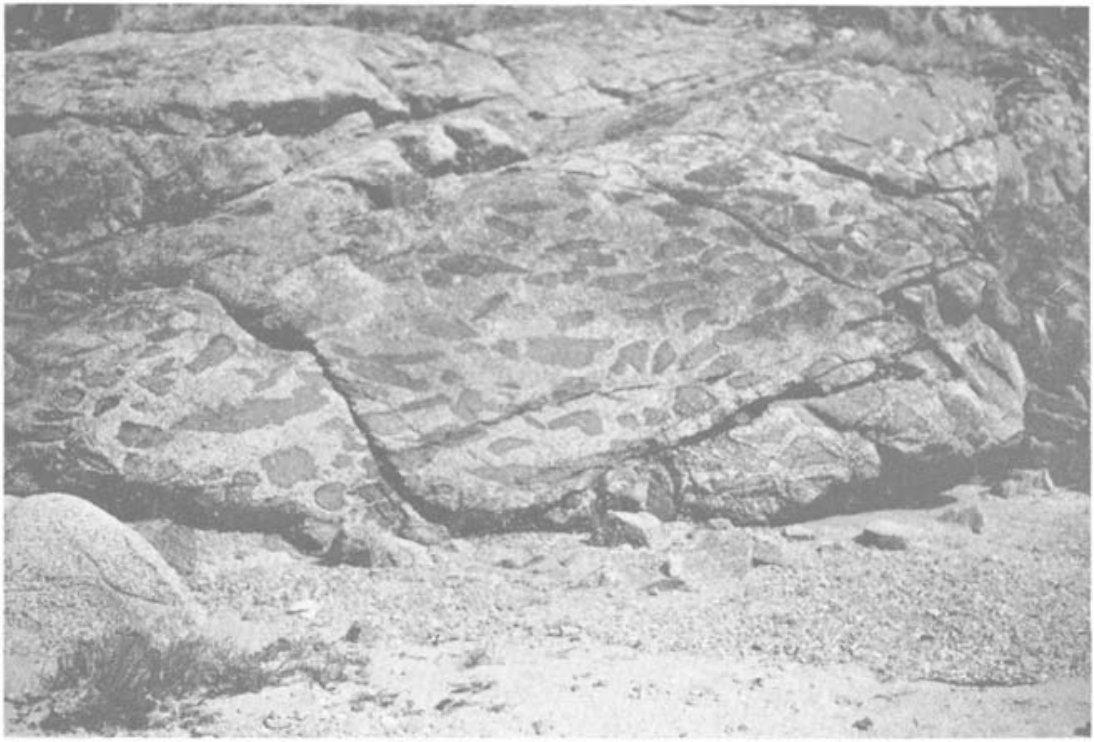

FIG. 1.- Basic dioritic xenoliths enclosed in the tonalite of the Foyers "Granite" complex. Shore of Loch Farraline at Errogie.

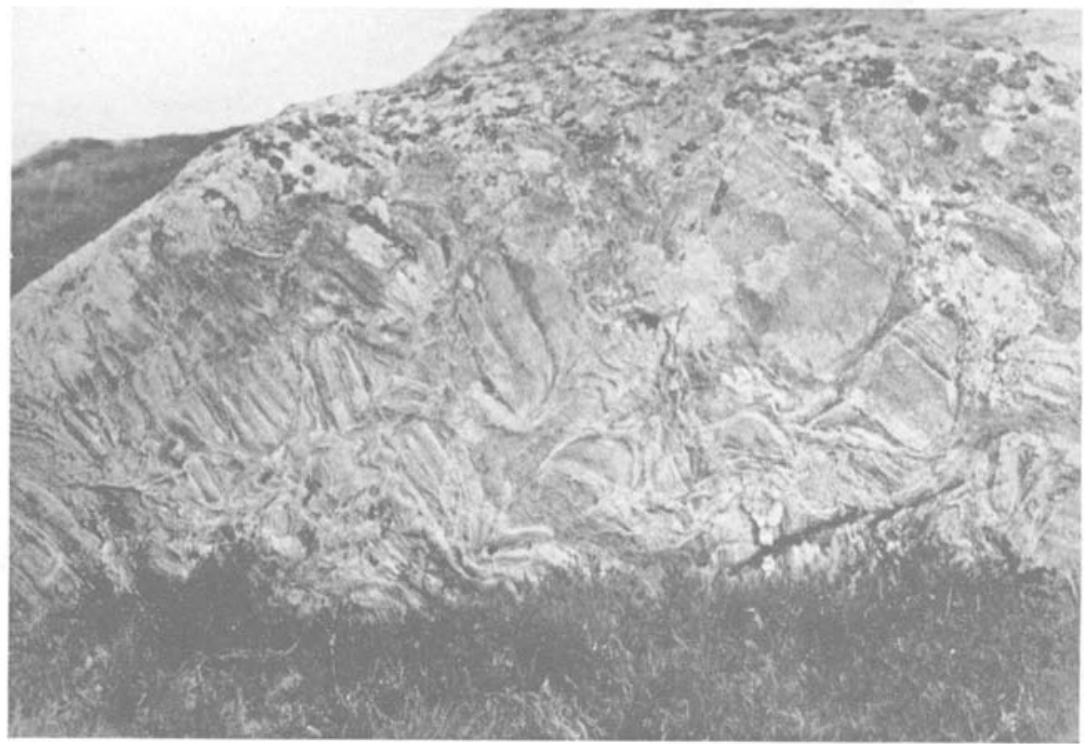

FIG. 2.- "Intrusion breccia" of schist fragments on the margin of the Foyers "Granite" complex. Summit of Carn Gairbhthinn. 